\title{
Special issue on
}

\section{(In)tolerance and (in)civility in public discourse from multidisciplinary perspectives}

\section{Guest Editor:}

Svetlana Kurteš 



\section{TABLE OF CONTENTS}

Svetlana Kurteš, (In)tolerance and (in)civility in public discourse and (the promotion of) interculturality from multidisciplinary perspectives: Theory, practice, pedagogy

Michael Hinner, Developing a curriculum designed to overcome intolerance: A conceptual approach

Tatiana Larina, Vladimir Ozyumenko, Svetlana Kurteš, Deconstructing the linguacultural underpinnings of tolerance: AngloSlavonic perspectives

Sylke Meyerhuber, Deconstructing impoliteness in professional discourse: The social psychology of workplace mobbing, A crossdisciplinary contribution with conclusions for the intercultural workplace.

Zorica Trajkova, Media framing of the Macedonia name change issue: the use of fear-inducing language strategies

Silvana Neshkovska, Impoliteness on the political stage: The case of the 2019 final Macedonian presidential debate

Alcina Pereira de Sousa, Fostering civility and politeness awareness in professional discourse: Critical genre analysis of course books in professional communication 
